\title{
Türkçe Öğretmenliği ve Türk Dili ve Edebiyatı Bölümü Öğrencilerinin Yaşam Boyu Öğrenme Eğilimlerinin Mesleğe Yönelik Tutumları İle İlişkisi
}

\section{The Correlation between Life-Long Learning Tendencies of Students of Turkish Teaching and Turkish Language and Literature Departments and Their Attitudes toward Profession}

\author{
Berna ÜRÜN KARAHAN \\ Kafkas Üniversitesi, Eğitim Fakültesi, Sosyal Bilimler ve Türkçe Eğitimi Bölümü, Türkçe Eğitimi A.B.D., Kars. \\ e-posta: urunkarahan@gmail.com
}

Atıf: Ürün-Karahan, B. (2017). Türkçe Öğretmenliği ve Türk Dili ve Edebiyatı Bölümü Öğrencilerinin Yaşam Boyu Öğrenme Eğilimlerinin Mesleğe Yönelik Tutumları İle İlişkisi. E-Kafkas Eğitim Araştırmaları Dergisi, 4(3), 45-58.

$\ddot{\text { ozet }}$

Yaşam boyu öğrenme bireyin yaşamı boyunca bilgi edinme ve bu bilgiyi anlamlandırma sürecini kapsar. Bu öğrenme formal ya da informal olabilir. Bu nedenle birey her yerde ve her durumda öğrenme ger çekleştirebilir. Burada dikkat edilmesi gereken bilginin doğru edinilmesi ve kullanılabilir olmasıdır. Bu çalışmada amaç Eğitim Fakültesi ile Fen Edebiyat Fakültesi öğrencileri arasındaki yaşam boyu öğrenme eğilimlerinin mesleğe yönelik tutumları ile ilişkisini incelemektir. Türkçe Öğretmenliği son sınıf öğrencileri ve Fen Edebiyat Fakültesi Türk Dili ve Edebiyatı bölümünde Pedagojik Formasyon alan öğrencilere ölçekler uygulanmıştır. Veriler Coşkun Diker (2009) tarafindan geliştirilen "Yaşam Boyu Öğrenme Eğilimleri Ölçeği” ve Temizkan (2008) tarafından hazırlanan “Türkçe Öğretmenliği Mesleğine Yönelik Tutum Ölçeği” ile toplanmıştır. Elde edilen bulgulara göre; ortalamalara bakıldığında TDE öğretmen adaylarının daha iyi durumda olduğu tespit edilmiştir. Korelasyon sonuçlarına göre tutum ölçeğinin alt boyutlarından bazıları arasında anlamlı ilişki varken yaşam boyu öğrenme eğilimleri ile mesleğe bağlılık alt boyutu arasında negatif yönde zayıf bir ilişki tespit edilmiştir. Cinsiyet, yaş, bölüm ve mezun olunan lise türü değişkenlerine göre ise bazı farklılıklar tespit edilmiştir.

Anahtar kelimeler: Tutum, Yaşam boyu öğrenme, öğretmenlik mesleği.

\begin{abstract}
Life-long learning includes the process of acquiring knowledge and making this knowledgesensethroughout an individual's life. This learning can be formalor informal. Therefore, the individual may learneverywhere under any circumstances. Here, the point to take into account is that knowledge should be accurately acquired and can be used. The aim of this study is to examine the correlationbetween life-long learning tendencies of students of Faculty of Education and Faculty of Arts and Sciencesand their attitudes toward the profession. The scales were applied to senior students from Turkish Teaching department and students receiving pedagogical formation from Turkish Language and Literature students from Faculty of Artsand Sciences. The data were collected by using the "Life-Long LearningScale" developed by Coşkun Diker (2009) and "The Scale of Attitude Toward Turkish Teaching Profession" prepared by Temizkan (2008). According to the results it was found that teacher candidates from TLL department had higher mean scores. According to the correlation results, it was determined that while there was a significant correlation among some of the subscales in the attitude scale, a negative weak correlation was found between life-long learning tendencies and the subscale of professional commitment. Some differences were found based on variables of sex, age, department and type of high school they graduated from.
\end{abstract}

Keywords: Attitude, Life-long learning, teaching profession.

GíRis

Eğitim ve öğretim bir süreçtir. Bu süreç bireyin tüm hayatı boyunca karşılaştığı formal ve informal öğrenmeleri kapsar. Yani birey doğduğundan itibaren önce aile, çevre sonra okul ve diğer öğretim kurumlarında bilgi ve davranış edinmeye çalışır. Ancak bu bilgi edinimi sadece yaşamın belli bir bölümüyle sınırlı değildir. Öğrenme birey için hayat boyu sürer. Zira artık günümüzde bireylerin hem çalışma hem de sosyal hayatta var olabilmeleri için sadece okullarda edindikleri bilgi yetmemektedir. Bu nedenle öğrenme bireyin var oluşundan ölümüne kadar süren bir davranış biçimidir (Miser, 2006; Duman, 2007; Akkuş, 2008).

"Eğitim, bireyin kişisel, zihinsel, fiziksel ve sosyal gelişim alanlarına bir bütün olarak katkı sunması, ihtiyaç duyduğu bilgi donanımını sağlaması açısından temel bir hak olarak kabul edilmektedir. Bir ülkenin kalkınmışlık düzeyini gösteren en önemli ölçüt bireye sunduğu eğitim olanaklarıdır. Gelişen dünyayla birlikte kuşkusuz eğitim sistemleri de bunun bir parçası olmaktadır. Hatta bu gelişim eğitim olanaklarıyla diğer toplumlara yayılmakta ve ilerlemenin en önemli araçlarından biri olmaktadır" (Yaman ve Yazar, 2015:1554). Bu nedenle eğitim-öğretim hem süreç olarak hem de içerik olarak dikkatle incelenmeli ve varsa sorunlar giderilmelidir.

"Yaşadığımız çağda bilgiler çoğalsa bile yaşanan gelişme ve buna bağlı değişimler sonucunda üretilen bilgiler hızla eskimekte ve geçerliliğini yitirebilmektedir. Bu nedenle, yaşam boyu öğrenme günümüz dünyasında bireylere gerekli olan nitelikli güncel bilgi ve becerilerin kazandırılmasında önemli rol oynamaktadır. Toplumsal yasam içindeki bu farklı öğrenme ortamları yasam boyu eğitim/öğrenme kavramlarının önem kazanmasına ve akademik araştırmalar bağlamında daha çok tartışılmasına zemin hazırlamıştır” (Oral ve Yazar, 2015:2). Günümüz 
dünyasında sürekli ve hızlı bir değişim söz konusudur. Öyle ki bu değişimler bir insanın ömründen daha kısadır. Bu nedenle öğrenmenin gerçekleşmesini sağlarken sunulacak öğretim programlarının yaşam boyu sürecek şekilde, yaparak-yaşayarak öğrenme yöntemine uygun bir şekilde tasarlanmalıdır (Kılıç,2014).

Ülkemizde eğitim-öğretim denince akla okullar gelmektedir. Elbette okullar sadece binalardan ibaret değildir. Bu kurumlarda görev yapan ve bireyleri geleceğe hazırlayan programlar ve öğretmenler birer rehber konumundadırlar. Hızla gelişen dünyaya ayak uydurmak, gelişmeleri takip etmek ve bu gelişmeleri anlayıp, özümseme becerilerine sahip olan öğrenciler yetiştirebilmek için öğretmenlere önemli görevler düşmektedir. "Artık okul eğitimi süresinde edinilen bilgi ve beceriler ile ömür boyu mesleğini etkili biçimde yapabilmek de neredeyse imkânsız hale gelmektedir. Bireyler zaman zaman çeşitli eğitimlerden geçmek, yeni bilgiler öğrenmek ve kendilerini yenilemek zorundadırlar"(Ayra, Kösterelioğlu ve Çelen, 2016:499).

Yaşam boyu öğrenme aslında yaparak-yaşayarak öğrenmeye benzemektedir. Çünkü öğrenmenin nerede ve nasıl gerçekleşeceğini bilmez birey. Yaparak-yaşayarak öğrenen birey de öğrenme daha hızlı ve kalıcı olur bu da başarı anlamına gelir. "Yaşam boyu öğrenme anlayışı öğrenmenin zaman ve mekânla sınıflanmadığııı, her yaşta ve her yerde öğrenmenin olabileceğini ifade etmektedir" (Yılmaz, 2016:254).

Yaşam boyu öğrenme günümüzde artık zorunlu hale gelmiştir. Sürekli değişen ve hızla eskiyen bilgiler bireyleri yeni bilgiler edinme durumunda bırakmıştır. "Bilgi ve iletişim teknolojilerinde yaşanan hızlı gelişmeler, bireyin bilgisini ve yeterliliklerini geliştirmesini zorunlu hale getirmiştir. Bu bağlamda, bireyin yaşadığı ortam ve zamanın ihtiyaçlarına ayak uydurabilmesi için sahip olması gereken en önemli becerilerden biri de yaşam boyu öğrenmedir" (Özgür, 2016:22).

Yaşam boyu öğrenme kavramı ilk kez 1800'lü yıllarda Grundtvig tarafindan kullanılmış, temellerini ise Commenius'un görüşleri oluşturmuştur (Wain, 2000:36 akt. Hoşgörürür, 2016). Kılıç ve Tuncel (2014) yaşam boyu öğrenmenin gelişmiş ülkeler gibi hemen her ülkenin eğitim politikalarında rol oynadığı ve temel bir beceri olarak bireylere kazandırılmaya çalışıldığını ifade etmektedirler.

$\mathrm{Bu}$ beceriyi bireylere öğretecek olan öğretmenlerdir. Sürekli değişen ve yenilenen programlar, hızla değişen teknoloji ve bilgiye ulaşma gücü bireylerin beceri edinimi ya da kullanımı ile ilgili sorunlara yol açabilir. Bu nedenle öğretmenlerin bu beceri ile ilgili duygu ve düşünceleri üzerinde çalışılması gereken konulardandır. "Birçok görev ve sorumluluk gerektiren öğretmenlik mesleğini, layıkıyla yapabilecek yeterliğe sahip öğretmenlerin, eğitim sisteminde yerlerini almaları önem taşımaktadır” (Ayra ve Kösterelioğlu, 2015:19).

Yaşam boyu öğrenme becerisinin kazandırılması, bireyin hayatta karşılaşıı̆ı durumları kendi kendine çözebilmesi ve bilgi edinimini kendi başına gerçekleştirebilmesine yardımcı olur. Zira erken yaşlarda edinilen bilgiler zamanla unutulabilir ya da eskiyebilir. Bu nedenle bu beceriye sahip öğretmenlerin bireyler yol göstermesi gerekir (Knowles, 1996).

Çam ve Üstün (2016), öğretmenliğin güncelliği ve çağın gereklerini yerine getiren bireylerle daha sağlıklı bir meslek olacağını ifade etmektedirler. Mesleğin gereklerini yerine getirirken yeni gelişmelere ve taze bilgilere ulaşan ve kendini güncelleyen bireylerin şüphesiz ki öğrencilerine de katkısı büyük olacaktır. Bu noktada yaşam boyu öğrenme karımıza çıkmaktadır.

Öğretmenlerin bu becerinin edinimi ile ilgili olumlu model olmaları ve öğrenmeye karşı istekli bireyler yetiştirmeye çalışmaları önemlidir. "Öğrenmeye doymayan bir nesil demek modern dünyanın önde gidenlerinden olmak demektir. Öğrenmeye istekli bireyler kendilerini mesleki, kişisel, sosyal ve kültürel alanlarda geliştirebilmektedir. Bu da bireylerin daha kaliteli bir yaşam sürmelerine olanak sağlayacaktır" (Çam ve Üstün 2016:461)

"Öğretmen, eğitim sisteminin temel taşlarından biridir. Öğretim sürecini planlama, uygun yöntem, teknik ve araç-gereçlerin etkin kullanımını sağlama, öğrenciyle etkileşim halinde bulunarak öğretim sürecini değerlendirme gibi pek çok aşamanın başarılı bir biçimde gerçekleştirilmesi büyük bir oranda öğretmene bağlıdır. Bunun için öncelikle öğretmenin alana ilişkin yeterli bir bilgi ve beceriyle donatılması gerekir. Ancak başarının sağlanmasında salt bilgi yeterli değildir. Tutumların da önemli bir etkisi söz konusudur” (Çetinkaya, 2009:299).

"Öğretmen adaylarının seçiminde öğretmenlik mesleğini seven ve isteyen adayların seçilmesi, nitelikli öğretmen yetiştirmenin ilk adımıdır, denilebilir. Bu bağlamda, öğretmen yetiştiren kurumlarda öğrenim gören öğretmen adaylarının öğretmenlik mesleğine ilişkin tutumlarının incelenmesi ve ortaya çıkan bulgular doğrultusunda bu tutumlarının geliştirilmesi için gerekli önlemlerin alınması şarttır" (Özder, Konedrali ve Zeki, 2010:256).

Unutulmamalıdır ki sağlıklı bir toplumun temelini oluşturan en önemli unsur eğitim sistemi ve bu sistemin etkili bir şekilde işlemesidir. Bu sistemin temel öğesinin öğretmen olduğu ve diğer öğelere göre etki gücünün daha fazla olduğu bilinmektedir (Çapa ve Çil, 2000).

$\mathrm{Bu}$ çalışmanın temelini oluşturan ve her alanda varlık gösterecek insanları yetiştiren öğretmenlerin ve öğretmenlik mesleğinin daha hassasiyetle üzerinde durulması gerekir. Bir ülkenin geleceğini yetiştiren ve işi insan olan bu bireylerin özel beceri alanları ile mesleğe yönelik tutum ve algıları ile günümüz dünyasında oldukça gerekli olan yaşam boyu öğrenme eğilimleri dikkatle incelenmelidir. Başbay, Ünver ve Bümen'e (2009) göre öğretmenlerin, bu mesleğe yönelik olumlu tutum geliştirmeleri öğretmen yetiştirme programlarının önemli amaçları arasındadır. Çünkü Gürbüz ve Kışoğlu'nun (2007) da belirttiği gibi meslekle ilgili geliştirilen olumlu 
tutum o alandaki başarının önemli bir belirleyicisidir. Bu amaçla çalışmada öğretmen adayları ve pedagojik fomasyon grubu öğrencilerinin yaşam boyu öğrenme eğilimleri ve mesleğe yönelik tutumları ile bu kavramların çeşitli değişkenlere göre farklılık gösterip göstermediği incelenmiştir.

\section{Araştırma modeli}

\section{YÖNTEM}

Bu araştırma, Türkçe öğretmenliği bölümü öğrencileri ile Türk Dili ve Edebiyatı bölümü öğrencilerinin ders çalışma yaklaşımlarının karşılaştırılmasına yönelik olarak tarama modelinde gerçekleştirilmiştir. "Tarama modelleri, geçmişte ya da hâlen var olan bir durumu var olduğu şekliyle betimlemeyi amaçlayan araştırma yaklaşımlarıdı"” (Karasar, 2010:77). "Tarama araştırmalarında amaç; çok sayıda katılımcının görüş ya da özelliklerinin belirlenmesidir” (Büyüköztürk, 2008:248).

\section{Evren ve örneklem}

Araştırmanın örneklemini; 2016-2017 eğitim-öğretim yılında Kafkas Üniversitesi Eğitim Fakültesi Sosyal Bilimler ve Türkçe Eğitimi Bölümü’nde öğrenim gören son sınıf öğrencileri ile Fen Edebiyat Fakültesi Türk Dili ve Edebiyatı bölümünde okuyan ve pedagojik formasyon alan son sınıf öğrencileri oluşturmuştur. Öğrencilerin demografik özelikleri ile ilgili bilgiler tablo 1'de verilmiştir.

Tablo 1.

Örneklem grubunda yer alan öğrencilerin demografik özellikleri

\begin{tabular}{|c|c|c|c|}
\hline $\begin{array}{l}\text { Demografik } \\
\text { Özellikler }\end{array}$ & & Frekans (f) & Yüzde (\%) \\
\hline \multirow{3}{*}{ Cinsiyet } & $\mathrm{K}_{1 \mathrm{Z}}$ & 107 & 53.8 \\
\hline & Erkek & 92 & 46.2 \\
\hline & Toplam & 199 & 100.0 \\
\hline \multirow{4}{*}{ Yaş } & $1(21,22,23)$ & 111 & 55.8 \\
\hline & $2(24,25,26)$ & 54 & 27.1 \\
\hline & $3(27,28,29)$ & 34 & 17.1 \\
\hline & Toplam & 199 & 100.0 \\
\hline \multirow[t]{3}{*}{ Bölüm } & 1(Türkçe) & 109 & 54.8 \\
\hline & 2(TDE) & 90 & 45.2 \\
\hline & Toplam & 199 & 100.0 \\
\hline \multirow[t]{4}{*}{ Mez olunan lise türü } & 1(düz lise) & 154 & 77.4 \\
\hline & 2(anadolu lis.) & 25 & 12.6 \\
\hline & 3(meslek lis.) & 20 & 10.1 \\
\hline & Toplam & 199 & 100.0 \\
\hline
\end{tabular}

\section{Veri toplama araçlart}

Yaşam Boyu Öğrenme Eğilimleri Ölçeği: Ölçek Coşkun Diker (2009) tarafindan hazırlanmış bir doktora çalışmasının ürünüdür. Aracın geçerlik ve güvenirlik çalışmaları 600 pilot ve 1500 asıl uygulama olmak üzere 2100 kişilik bir örneklem üzerinde gerçekleştirilmiştir. Ölçek 4 alt boyuttan oluşmaktadır. Bunlar; motivasyon: 1,2,3,4,5,6 bütün maddeler olumlu, sebat: 7,8,9,10,11,12 bütün maddeler olumlu, öğrenmeyi düzenlemede yoksunluk: 13,14,15,16,17,18 bütün maddeler olumsuz, merak yoksunluğu: 19,20,21,22,23,24,25,26,27 bütün maddeler olumsuzdur. 6'lı likert yapısında olan ölçek 27 maddeden oluşmaktadır. Ölçekten alınabilecek en düşük puan 27, en yüksek puan ise 162 olarak belirlenmiştir. Ölçek, "çok uyuyor" 6, "kismen uyuyor" 5, "çok az uyuyor" 4, "çok az uymuyor" 3, "kısmen uymuyor" 2, "hiç uymuyor" 1 olarak kodlanmıştır. Üniversite öğrencilerinin yaşam boyu öğrenme eğilimlerinin belirlenmesinde toplam ortalama puanlar ve standart sapmalar ile ölçekten alınabilecek minumum, orta ve maksimum puanlar ölçüt olarak alınmıştır. Ölçeğin cronbach alfa güvenirlik katsayısı .91 olarak tespit edilmiştir.

Türkçe Öğretmenliği Mesleğine Yönelik Tutum Ölçeği: Ölçek, Temizkan (2008) tarafindan geliştirilmiştir. Beşli likert tipinde olan tutum ölçeği, geçerlik ve güvenirlik analizleri için 55 kişilik bir öğrenci grubuna uygulanmıştır. Puanlamalar "Kesinlikle Katılıyorum”, "Katılıyorum”, "Kararsızım”, "Katılmıyorum”, "Kesinlikle Katılmıyorum" şeklinde sıralanmaktadır. Ölçeğin kapsam geçerliğini sağlamak üzere madde toplam test korelasyonu, yapı geçerliğini sağlamak amacıyla da faktör analizi yapılmıştır. Ölçekte yer alan birinci faktör (mesleğe ilgi duyma) dört maddeden, ikinci faktör (mesleğe bağlılık) altı maddeden, üçüncü faktör (mesleği sevme) altı maddeden, dördüncü faktör (mesleğin gerekliliğine inanma) beş maddeden ve beşinci faktör (meslekle ilgili yeterlilik düzeyleri) on maddeden oluşmaktadır. 35 maddelik tutum ölçeğinin Cronbach Alpha katsayısı .78 olarak belirlenmiştir. Geçerlik ve güvenilirlik işlemleri sonucunda ölçekteki madde sayısı 31'e düşmüş, güvenilirlik katsayısı da .86 olarak tespit edilmiştir. 


\section{BULGULAR}

Çalışmada Türkçe öğretmeni adayları ve Türk Dili ve Edebiyatı öğretmeni adaylarının yaşam boyu öğrenme eğilimlerinin mesleğe yönelik tutumları ile ilişkisi incelenmiştir. $\mathrm{Bu}$ doğrultuda önce öğretmen adaylarının yaşam boyu öğrenme eğilimleri ve mesleğe yönelik tutumlarının ne düzeyde olduğunu tespit edebilmek amacıyla ortalama değerlere bakılmıştır. Bulgular tablo 2'de verilmiştir.

Tablo 2.

Ortalamalar

\begin{tabular}{|c|c|c|c|c|}
\hline Değişkenler & Bölüm & $\mathbf{N}$ & $\bar{X}$ & Ss \\
\hline Mesleğe İlgi & Türkçe & 109 & 15,02 & \\
\hline Duyma (mid) & TDE & 90 & 15,88 & 2,51 \\
\hline Mesleğe Bağlılık & Türkçe & 109 & 24,77 & 4,25 \\
\hline$(\mathrm{mb})$ & TDE & 90 & 27,61 & 4,09 \\
\hline Mesleği Sevme & Türkçe & 109 & 18,62 & 3,31 \\
\hline (ms) & TDE & 90 & 19,22 & 2,56 \\
\hline Mesleğin Gerekli & Türkçe & 109 & 19,43 & 4,00 \\
\hline liğine İ́nanma (mgi) & TDE & 90 & 19,64 & 3,29 \\
\hline Meslekle İlgili & Türkçe & 109 & 33,70 & 4,59 \\
\hline $\begin{array}{l}\text { Yeterlilik Düzeyleri } \\
\text { (miyd) }\end{array}$ & TDE & 90 & 35,70 & 4,37 \\
\hline Yaşam Boyu & Türkçe & 109 & 87,53 & 18,06 \\
\hline Öğrenme Eğilimleri & TDE & 90 & 85,05 & 22,31 \\
\hline
\end{tabular}

Tablo 2 incelendiğinde öğretmen adaylarının tutum ölçeğinin "mesleğe ilgi duyma" alt boyutundan alınabilecek en yüksek puan 20, en düşük puan ise 4'tür. Ortalamalara bakıldığında her iki bölümde okuyan öğretmen adaylarının ortalamalarının iyi düzeyde olduğu az bir farkla TDE öğrencilerinin mesleğe karşı ilgi durumlarının daha iyi düzeyde olduğu söylenebilir. Tutum ölçeğinin "mesleğe bağlılık" alt boyutundan alınabilecek en yüksek puan 30, en düşük puan ise 6'dır. Bu durumda ortalamalara bakıldığında her iki bölümde okuyan öğretmen adaylarının ortalamalarının iyi düzeyde olduğu yine az bir farkla TDE öğrencilerinin mesleğe bağlılık durumlarının daha iyi düzeyde olduğu söylenebilir. "Mesleği sevme" alt boyutunda ise alınabilecek en yüksek puan 30, en düşük puan ise 6'dır. Ortalamalara bakıldığında her iki bölümde okuyan öğretmen adaylarının ortalamalarının orta düzeyde olduğu az bir farkla TDE öğrencilerinin mesleği daha çok sevdikleri söylenebilir. Ölçeğin "mesleğin gerekliliğine inanma" alt boyutundan alınabilecek en yüksek puan 25 , en düşük puan ise 5'tir. Bu durumda ortalamalara bakıldığında her iki bölümde okuyan öğretmen adaylarının ortalamalarının iyi düzeyde olduğu yine az bir farkla TDE öğrencilerinin mesleğin gerekli olduğuna inanma durumlarının daha iyi düzeyde olduğu söylenebilir. "Meslekle ilgili yeterlilik düzeyleri" alt boyutundan alınabilecek en yüksek puan 50, en düşük puan ise 10 'dur. Ortalamalara bakıldığında her iki bölümde okuyan öğretmen adaylarının ortalamalarının orta düzeyde olduğu yine az bir farkla TDE öğrencilerinin meslekle ilgili yeterlilik düzeylerinin daha iyi durumda olduğu söylenebilir. "Yaşam Boyu Öğrenme Eğilimleri” ölçeğinden alınabilecek en düşük puan 27, en yüksek puan ise 162'dir. Bu durumda ortalamalara bakıldığında her iki bölümde okuyan öğretmen adaylarının ortalamalarının orta düzeyde olduğu az bir farkla Türkçe öğrencilerinin yaşam boyu öğrenme eğilimlerinin daha iyi düzeyde olduğu söylenebilir.

Çalışmada tutum ölçeğinin alt boyutları (mid, mb, ms, mgi, miyd,) ve yaşam boyu öğrenme eğilimleri arasındaki ilişkilerini incelemek amacıyla Pearson korelasyon katsayıları hesaplanmıştır. Bulgular tablo 3'te verilmiştir.

Tablo 3.

Korelasyonlar

\begin{tabular}{|c|c|c|c|c|c|}
\hline Değişkenler & 2 & 3 & 4 & 5 & 6 \\
\hline 1. $\mathrm{mid}$ &, $586 * *$ &, $573 * *$ & ,630** &, $524 * *$ &,- 024 \\
\hline 2. $\mathrm{mb}$ & &, $524 * *$ &, $500 * *$ &, $347 * *$ &,- 048 \\
\hline 3. $\mathrm{ms}$ & & &, $711 * *$ &, $367 * *$ & ,004 \\
\hline 4. mgi & & & & ,416** & ,008 \\
\hline 5. miyd & & & & & ,089 \\
\hline 6. yaş bo.ö & & & & & \\
\hline
\end{tabular}

Korelasyon katsayıları incelendiğinde, en yüksek pozitif yönde ilişkinin tutum ölçeğinin alt boyutlarından mesleği sevme ile mesleğin gerekliliğine inanma arasında olduğu (r=,711**), görülmektedir. Diğer yandan orta düzeyde pozitif yönde bir ilişki de tutum ölçeğinin alt boyutları arasında görülmektedir. Bunlar mesleğe ilgi duyma 
ile mesleğin gerekliliğine inanma arasında $\left(\mathrm{r}=, 630^{* *}\right)$, mesleğe ilgi duyma ile mesleğe bağl1lık arasında $(\mathrm{r}=$ , $\left.586^{* *}\right)$, mesleğe ilgi duyma ile mesleği sevme arasında $\left(\mathrm{r}=, 547^{* *}\right)$ olduğu dikkat çekmektedir. Mesleğe yönelik duygu ve düşüncelerin birbirini olumlu anlamda desteklediği ve birinin artışından diğerinin de olumlu yönde arttı̆̆ söylenebilir. Buna ek olarak negatif yönde en zayıf ilişkinin tutum ölçeğinin alt boyutu olan mesleğe bağlllık ile yaşam boyu öğrenme eğilimleri arasında $(\mathrm{r}=-, 048)$ olduğu görülmektedir. Buna göre öğretmen adaylarının yaşam boyu öğrenme eğilimleri azaldıkça mesleğe yönelik tutumları artmaktadır denebilir. Bunun dışında öğretmen adaylarının yaşam boyu öğrenme eğilimleri ile mesleğe yönelik tutumları arasında diğer alt boyutlarda herhangi anlamlı bir farklılık tespit edilmemiştir.

Çalışmada Türkçe öğretmeni adayları ve Türk Dili ve Edebiyatı öğretmeni adaylarının yaşam boyu öğrenme eğilimlerinin ve mesleğe yönelik tutumlarının cinsiyet değişkenine göre faklılık gösterip göstermediğini tespit edebilmek amacıyla t testi yapılmıştır. Elde edilen bulgular tablo 4'te verilmiştir.

Tablo 4.

Cinsiyet değişkenine göre t testi sonuçları

\begin{tabular}{|c|c|c|c|c|c|c|c|c|}
\hline & Cinsiyet & & $\mathbf{N}$ & $\bar{X}$ & $\mathbf{S}$ & Sd & $\mathbf{t}$ & $\mathbf{p}$ \\
\hline \multirow{2}{*}{$\begin{array}{l}\text { Mid } \\
\text { Türkçe }\end{array}$} & Kiz & & 57 & 15,77 & 2,83 & \multirow[b]{2}{*}{96,89} & \multirow[b]{2}{*}{2,52} & \multirow[b]{2}{*}{, 01} \\
\hline & Erkek & & 52 & 14,21 & 3,59 & & & \\
\hline \multirow{2}{*}{$\begin{array}{l}\text { Mid } \\
\text { TDE }\end{array}$} & $\mathrm{K} 1 \mathrm{Z}$ & $\mathrm{K} 1 \mathrm{Z}$ & 50 & 15.94 & 2.11 & \multirow[b]{2}{*}{67,97} & \multirow[b]{2}{*}{, 21} & \multirow[b]{2}{*}{, 83} \\
\hline & Erkek & Erkek & 40 & 15.82 & 2.97 & & & \\
\hline \multirow{2}{*}{$\begin{array}{l}\mathrm{Mb} \\
\text { Türkçe }\end{array}$} & Kiz & Kiz & 57 & 26,33 & 4,31 & \multirow[b]{2}{*}{105,50} & \multirow[b]{2}{*}{4,33} & \multirow[b]{2}{*}{, 00} \\
\hline & Erkek & Erk & 52 & 23,05 & 3,48 & & & \\
\hline \multirow{2}{*}{$\begin{array}{l}\mathrm{Mb} \\
\mathrm{TDE}\end{array}$} & $\mathrm{K} 1 \mathrm{Z}$ & $\mathrm{K} 1 \mathrm{z}$ & 50 & 28,64 & 3.12 & \multirow[b]{2}{*}{64,16} & \multirow[b]{2}{*}{2,76} & \multirow[b]{2}{*}{, 00} \\
\hline & Erkek & Erk $\epsilon$ & 40 & 26,32 & 4.78 & & & \\
\hline \multirow{2}{*}{$\begin{array}{l}\text { Ms } \\
\text { Türkçe }\end{array}$} & K1z & K1z & 57 & 19,70 & 1,90 & \multirow[b]{2}{*}{70,99} & \multirow[b]{2}{*}{3,77} & \multirow[b]{2}{*}{, 00} \\
\hline & Erkek & $\overline{\text { Erk } \epsilon}$ & 52 & 17,44 & 4,06 & & & \\
\hline \multirow{2}{*}{$\begin{array}{l}\text { Ms } \\
\text { TDE }\end{array}$} & Kız & $\mathrm{K} 1 \mathrm{Z}$ & 50 & 19,48 & 2,45 & \multirow[b]{2}{*}{80,14} & \multirow[b]{2}{*}{1,06} & \multirow[b]{2}{*}{, 28} \\
\hline & Erkek & Erk $\epsilon$ & 40 & 18,90 & 2,68 & & & \\
\hline \multirow{2}{*}{$\begin{array}{l}\text { Mgi } \\
\text { Türkçe }\end{array}$} & $\mathrm{K} 1 \mathrm{Z}$ & $\mathrm{K} 1 \mathrm{Z}$ & 57 & 20,35 & 2,73 & \multirow[b]{2}{*}{78,58} & \multirow[b]{2}{*}{2,57} & \multirow[b]{2}{*}{, 01} \\
\hline & Erkek & Erk $\epsilon$ & 52 & 18,42 & 4,87 & & & \\
\hline \multirow{2}{*}{$\begin{array}{l}\text { Mgi } \\
\text { TDE }\end{array}$} & $\mathrm{K} 1 \mathrm{Z}$ & Kız & 50 & 19,90 & 2,75 & \multirow[b]{2}{*}{67,97} & \multirow[b]{2}{*}{, 82} & \multirow[b]{2}{*}{, 41} \\
\hline & Erkek & Erk $\epsilon$ & 40 & 19,32 & 3,88 & & & \\
\hline & $\mathrm{K} 1 \mathrm{z}$ & K1z & 57 & 33,36 & 4,40 & & & \\
\hline Türkçe & Erkek & Erk $\epsilon$ & 52 & 34,07 & 4,81 & 103,59 &,- 80 &, 42 \\
\hline Miyd & $\mathrm{K} 1 \mathrm{Z}$ & Kız & 50 & 35,92 & 4,12 & & & \\
\hline TDE & Erkek & Erk $\epsilon$ & 40 & 35,42 & 4,70 & 78,27 &, 53 &, 59 \\
\hline Yaş.boy. & $\mathrm{K} 1 \mathrm{Z}$ & $\mathrm{K} 1 \mathrm{Z}$ & 57 & 88,59 & 15,80 & 96,06 & ,64 & \\
\hline $\begin{array}{l}\text { ögrr. } \\
\text { Türkçe }\end{array}$ & Erkek & Erk & 52 & 86,36 & 20,34 & & &, 52 \\
\hline & Kiz & $\mathrm{K} 1 \mathrm{z}$ & 50 & 84,66 & 23,49 & & & \\
\hline $\begin{array}{l}\text { ögr. } \\
\text { TDE }\end{array}$ & Erkek & Erk & 40 & 85,55 & 21,04 & 86,83 &,- 18 & ,85 \\
\hline
\end{tabular}

$\overline{\mathrm{p}<0,05}$

Tablo 4 incelendiğinde Türkçe öğretmeni adayları ve Türk Dili ve Edebiyatı öğretmeni adaylarının yaşam boyu öğrenme eğilimlerinin ve mesleğe yönelik tutumlarının cinsiyet değişkeni bakımından tutum ölçeğinin bazı alt boyutlarında anlamlı farklılık gösterdiği tespit edilmiştir. Mesleğe ilgi duyma alt boyutunda anlamlı farklılı̆ı̆ı Türkçe öğretmeni adayları adına olduğu, ortalamalara bakıldığında ise bu farkın kız öğrencilerin lehine olduğu görülmektedir. Mesleğe bağllık boyutunda ise her iki grupta yer alan öğretmen adayları lehine bir anlamlı farklılık olduğu görülmektedir. Ortalamalara bakıldığında TDE öğrencilerinin Türkçe öğrencilerine oranla daha iyi ortalamalara sahip olduğu dikkat çekmektedir. Buna ek olarak bu alt boyutta anlamlı farklılığın her iki grupta da kız öğrenciler lehine olduğu tespit edilmiştir. Mesleği sevme ve mesleğin gerekliliğine inanma alt boyutlarında da anlamlı bir farklılık olduğu ve bu farklılığın 2 alt boyutta da Türkçe öğrencileri adına olduğu, ortalamalara bakıldığında ise bu farkın kız öğrencilerin lehine olduğu tespit edilmiştir. Bunlara ek olarak tutum ölçeğinin diğer alt boyutlarında ve yaşam boyu öğrenme eğilimleri ölçeği bakımından herhangi anlamlı bir farklıllı̆a da rastlanmamıştır. 
Çalışmada Türkçe öğretmeni adayları ve Türk Dili ve Edebiyatı öğretmeni adaylarının yaşam boyu öğrenme eğilimlerinin ve mesleğe yönelik tutumlarının bölüm değişkenine göre faklılık gösterip göstermediğini tespit edebilmek amacıyla t testi yapılmıştır. Elde edilen bulgular tablo 5 'te verilmiştir.

Tablo 5 .

Bölüm değişkenine göre $t$ testi sonuçları

\begin{tabular}{|c|c|c|c|c|c|c|c|}
\hline & Bölüm & $\mathbf{N}$ & $\bar{X}$ & $\mathbf{S}$ & Sd & $\mathbf{t}$ & $\mathbf{p}$ \\
\hline \multirow[t]{2}{*}{ Mid } & Türkçe & 109 & 15,02 & 3,29 & \multirow{2}{*}{195,8} & \multirow{2}{*}{$-2,03$} & \multirow{2}{*}{, 04} \\
\hline & TDE & 90 & 15,88 & 2,51 & & & \\
\hline \multirow[t]{2}{*}{$\mathrm{Mb}$} & Türkçe & 109 & 24,77 & 4,25 & \multirow[b]{2}{*}{192,4} & \multirow[b]{2}{*}{$-4,77$} & \multirow[b]{2}{*}{, 00} \\
\hline & TDE & 90 & 27,61 & 4,09 & & & \\
\hline \multirow[t]{2}{*}{ Ms } & Türkçe & 109 & 18,62 & 3,31 & \multirow[b]{2}{*}{196,2} & \multirow[b]{2}{*}{$-1,40$} & \multirow[b]{2}{*}{, 16} \\
\hline & TDE & 90 & 19,22 & 2,56 & & & \\
\hline \multirow[t]{2}{*}{ Mgi } & Türkçe & 109 & 19,43 & 4,00 & \multirow[b]{2}{*}{197,0} & \multirow[b]{2}{*}{,- 40} & \multirow[b]{2}{*}{,68 } \\
\hline & TDE & 90 & 19,64 & 3,29 & & & \\
\hline \multirow[t]{2}{*}{ Miyd } & Türkçe & 109 & 33,70 & 4,59 & \multirow[b]{2}{*}{193,0} & \multirow[b]{2}{*}{$-3,11$} & \multirow[b]{2}{*}{, 00} \\
\hline & TDE & 90 & 35,70 & 4,37 & & & \\
\hline \multirow{2}{*}{$\begin{array}{l}\text { Yaş.boy. } \\
\text { öğr. }\end{array}$} & Türkçe & 109 & 87,53 & 18,06 & \multirow[b]{2}{*}{170,2} & \multirow[b]{2}{*}{, 86} & \multirow[b]{2}{*}{, 38} \\
\hline & TDE & 90 & 85,05 & 22,31 & & & \\
\hline
\end{tabular}

$\overline{\mathrm{p}<0,05}$

Tablo 5 incelendiğinde tutum ölçeğinin mesleğe ilgi duyma, mesleğe bağll1ık ve meslekle ilgili yeterlilik alt boyutlarında anlamlı farklılık olduğu tespit edilmiştir. Bu farklılığın TDE öğrencileri lehine olduğu görülmektedir. Tutum ölçeğinin diğer alt boyutlarında ve yaşam boyu öğrenme eğilimleri ölçeği adına bölüm değişkeni bakımından herhangi anlamlı bir farklılığa rastlanmamıştır.

Çalışmada Türkçe öğretmeni adayları ve Türk Dili ve Edebiyatı öğretmeni adaylarının yaşam boyu öğrenme eğilimlerinin ve mesleğe yönelik tutumlarının yaş değişkenine göre faklılık gösterip göstermediğini tespit edebilmek amaciyla Anova yapılmıştır. Elde edilen bulgular tablo 6'da verilmiştir. 
Tablo 6.

Yaş değişkenine göre Anova sonuçları

\begin{tabular}{|c|c|c|c|c|c|c|c|}
\hline Alt boyutlar & Bölüm & Gruplar & $\mathbf{N}$ & $\bar{X}$ & $\mathbf{S}$ & $\mathbf{F}$ & $\mathbf{p}$ \\
\hline \multirow{6}{*}{ Mid } & \multirow{3}{*}{ Türkçe } & $2(21,22,23)$ & 76 & 15,18 & 3,31 & \multirow{3}{*}{,813 } & \multirow{3}{*}{,44 } \\
\hline & & $3(24,25,26)$ & 31 & 14,51 & 3,28 & & \\
\hline & & $4(27,28,29)$ & 2 & 17,00 & 2,82 & & \\
\hline & \multirow{3}{*}{ TDE } & $2(21,22,23)$ & 35 & 15,91 & 3.10 & \multirow{3}{*}{, 028} & \multirow{3}{*}{,97 } \\
\hline & & $3(24,25,26)$ & 23 & 15,78 & 2.46 & & \\
\hline & & $4(27,28,29)$ & 32 & 15,93 & 1,81 & & \\
\hline \multirow{6}{*}{$\mathrm{Mb}$} & \multirow{3}{*}{ Türkçe } & $2(21,22,23)$ & 76 & 25,07 & 4,38 & \multirow[b]{3}{*}{4,15} & \multirow[b]{3}{*}{, 01} \\
\hline & & $3(24,25,26)$ & 31 & 23,58 & 3,50 & & \\
\hline & & $4(27,28,29)$ & 2 & 31,50 &, 70 & & \\
\hline & \multirow{3}{*}{ TDE } & $2(21,22,23)$ & 35 & 27,88 & 4,34 & \multirow{3}{*}{, 563} & \multirow{3}{*}{, 57} \\
\hline & & $3(24,25,26)$ & 23 & 26,82 & 3,65 & & \\
\hline & & $4(27,28,29)$ & 32 & 27,87 & 4,15 & & \\
\hline \multirow{6}{*}{ Ms } & \multirow{3}{*}{ Türkçe } & $2(21,22,23)$ & 76 & 18,81 & 3,21 & \multirow{3}{*}{1,50} & \multirow{3}{*}{, 22} \\
\hline & & $3(24,25,26)$ & 31 & 17,96 & 3,47 & & \\
\hline & & $4(27,28,29)$ & 2 & 21,50 & 3,53 & & \\
\hline & \multirow{3}{*}{ TDE } & $2(21,22,23)$ & 35 & 20,02 & 2,36 & \multirow{3}{*}{3,09} & \multirow{3}{*}{, 05} \\
\hline & & $3(24,25,26)$ & 23 & 18,91 & 2,41 & & \\
\hline & & $4(27,28,29)$ & 32 & 18,56 & 2,71 & & \\
\hline \multirow{6}{*}{ Mgi } & \multirow{3}{*}{ Türkçe } & $2(21,22,23)$ & 76 & 19,61 & 3,68 & \multirow{3}{*}{,685 } & \multirow{3}{*}{, 50} \\
\hline & & $3(24,25,26)$ & 31 & 18,83 & 4,79 & & \\
\hline & & $4(27,28,29)$ & 2 & 21,50 & 2,12 & & \\
\hline & \multirow{3}{*}{ TDE } & $2(21,22,23)$ & 35 & 20,22 & 2,71 & \multirow{3}{*}{1,08} & \\
\hline & & $3(24,25,26)$ & 23 & 18,95 & 3,29 & &, 34 \\
\hline & & $4(27,28,29)$ & 32 & 19,50 & 3,83 & & \\
\hline & & $2(21,22,23)$ & 76 & 33,43 & 4,38 & & \\
\hline & Türkçe & $3(24,25,26)$ & 31 & 34,19 & 5,05 &, 673 &, 51 \\
\hline Miyd & & $4(27,28,29)$ & 2 & 36,50 & 6,36 & & \\
\hline & & $2(21,22,23)$ & 35 & 35,28 & 4,57 & & \\
\hline & TDE & $3(24,25,26)$ & 23 & 35,13 & 3,92 & ,973 & ,38 \\
\hline & & $4(27,28,29)$ & 32 & 36,56 & 4,45 & & \\
\hline & & $2(21,22,23)$ & 76 & 87,43 & 18,08 & & \\
\hline Yaşam & & $3(24,25,26)$ & 31 & 87,83 & 18,55 & ,009 & ,99 \\
\hline Boyu öğr. & Türkçe & $4(27,28,29)$ & 2 & 86,50 & 19,09 & & \\
\hline & & $2(21,22,23)$ & 35 & 86,00 & 23,06 & & \\
\hline & TDE & $3(24,25,26)$ & 23 & 75,82 & 23,24 & 3,15 &, 04 \\
\hline & & $4(27,28,29)$ & 32 & 90,65 & 19,14 & & \\
\hline
\end{tabular}

$\mathrm{p}<0,05$

Tablo 6 incelendiğinde tutum ölçeğinin mesleğe bağlılık alt boyutunda ve yaşam boyu öğrenme eğilimleri ölçeğinde anlamlı farklılık olduğu tespit edilmiştir. Mesleğe bağlılık alt boyutunda Türkçe öğrencileri, yaşam boyu öğrenme eğilimleri alt boyutunda ise TDE öğrencileri adına anlamlı farklılık olduğu ortalamalara her iki alanda da 4.(27,28,29) grup lehine olduğu söylenebilir. Post-hoc Scheffe testi sonuçlarına göre farklılığın her iki alanda da 3-4 grupları arasında olduğu tespit edilmiştir.

Çalışmada Türkçe öğretmeni adayları ve Türk Dili ve Edebiyatı öğretmeni adaylarının yaşam boyu öğrenme eğilimlerinin ve mesleğe yönelik tutumlarının mezun olunan lise türü değişkenine göre faklılık gösterip göstermediğini tespit edebilmek amacıyla Anova yapılmıştır. Elde edilen bulgular tablo 7'de verilmiştir. 
Tablo 7.

Mezun olunan lise türü değişkenine göre t testi sonuçlart

\begin{tabular}{|c|c|c|c|c|c|c|c|}
\hline Alt boyutlar & Bölüm & Gruplar & $\mathbf{N}$ & $\bar{X}$ & $\mathbf{S}$ & $\mathbf{F}$ & $\mathbf{p}$ \\
\hline \multirow{6}{*}{ Mid } & \multirow{3}{*}{ Türkçe } & 1(düz) & 83 & 15,46 & 3,08 & \multirow{3}{*}{4,00} & \multirow{3}{*}{, 02} \\
\hline & & 2(Anadolu) & 18 & 14,11 & 3,54 & & \\
\hline & & 3(Meslek) & 8 & 12,50 & 3,77 & & \\
\hline & \multirow{3}{*}{ TDE } & $1($ düz $)$ & 71 & 15,76 & 2.54 & \multirow{3}{*}{3,35} & \multirow{3}{*}{, 04} \\
\hline & & 2(Anadolu) & 7 & 18,14 & 1.77 & & \\
\hline & & 3(Meslek) & 12 & 15,33 & 2,14 & & \\
\hline \multirow{6}{*}{$\mathrm{Mb}$} & \multirow{3}{*}{ Türkçe } & 1(düz) & 83 & 25,20 & 3,88 & \multirow[b]{3}{*}{3,61} & \multirow[b]{3}{*}{, 03} \\
\hline & & 2(Anadolu) & 18 & 24,38 & 5,65 & & \\
\hline & & 3(Meslek) & 8 & 21,12 & 2,53 & & \\
\hline & \multirow{3}{*}{ TDE } & 1(düz) & 71 & 27,42 & 4,16 & \multirow{3}{*}{3,78} & \multirow{3}{*}{, 02} \\
\hline & & 2(Anadolu) & 7 & 31,42 &, 78 & & \\
\hline & & 3(Meslek) & 12 & 26,50 & 3,70 & & \\
\hline \multirow{6}{*}{ Ms } & \multirow{3}{*}{ Türkçe } & 1(düz) & 83 & 18,71 & 3,43 & \multirow{3}{*}{1,26} & \multirow{3}{*}{,28 } \\
\hline & & 2(Anadolu) & 18 & 19,00 & 2,93 & & \\
\hline & & 3(Meslek) & 8 & 16,87 & 2,47 & & \\
\hline & \multirow{3}{*}{ TDE } & 1(düz) & 71 & 19,28 & 2,18 & \multirow{3}{*}{4,88} & \multirow{3}{*}{, 01} \\
\hline & & 2(Anadolu) & 7 & 21,28 & 2,05 & & \\
\hline & & 3(Meslek) & 12 & 17,66 & 3,89 & & \\
\hline \multirow{6}{*}{ Mgi } & \multirow{3}{*}{ Türkçe } & 1(düz) & 83 & 19,57 & 4,33 & \multirow{3}{*}{, 685} & \multirow{3}{*}{, 50} \\
\hline & & 2(Anadolu) & 18 & 19,50 & 2,61 & & \\
\hline & & 3(Meslek) & 8 & 17,75 & 2,71 & & \\
\hline & \multirow{3}{*}{ TDE } & 1(düz) & 71 & 19,80 & 3,28 & & \\
\hline & & 2(Anadolu) & 7 & 20,00 & 3,41 & 842 & ,43 \\
\hline & & 3(Meslek) & 12 & 18,50 & 3,34 & & \\
\hline & & 1(düz) & 83 & 33,73 & 4,83 & & \\
\hline & Türkçe & 2(Anadolu) & 18 & 33,61 & 4,06 &, 007 & ,99 \\
\hline Miyd & & 3(Meslek) & 8 & 33,62 & 3,42 & & \\
\hline & & 1(düz) & 71 & 35,29 & 4,34 & & \\
\hline & TDE & 2(Anadolu) & 7 & 39,57 & 3,15 & 3,20 & ,04 \\
\hline & & 3(Meslek) & 12 & 35,83 & 4,32 & & \\
\hline & & 1(düz) & 83 & 86,78 & 18,63 & & \\
\hline Yaşam & & 2(Anadolu) & 18 & 87,66 & 18,64 & & \\
\hline & Türkçe & & & & & ,752 & ,47 \\
\hline Boyu öğr. & & 3(Meslek) & 8 & 95,00 & 7,09 & & \\
\hline & & 1(düz) & 71 & 83,88 & 23,40 & & \\
\hline & TDE & 2(Anadolu) & 7 & 94,28 & 6,49 & ,720 & ,49 \\
\hline & & 3(Meslek) & 12 & 86,58 & 21,31 & & \\
\hline
\end{tabular}

$\overline{\mathrm{p}}<0,05$

Tablo 7 incelendiğinde tutum ölçeğinin alt boyutları olan mesleğe ilgi duyma, mesleğe bağl1lık, mesleği sevme ve meslekle ilgili yeterlilik alt boyutlarında anlamlı farklılık olduğu görülmektedir. Bu farkın ortalamalara bakıldığında mesleğe ilgi duyma alt boyutunda Türkçe öğrencileri için düz lise mezunları lehine olduğu Post-hoc Scheffe testi sonuçlarına göre 1-3 arasında ve TDE öğrencileri için Anadolu lisesi mezunları lehine olduğu ve Post-hoc Scheffe testi sonuçlarına göre 1-2 arasında ve 2-3 arasında olduğu tespit edilmiştir. Mesleğe bağlılık alt boyutunda ise yine Türkçe öğrencileri için düz lise mezunları lehine Post-hoc Scheffe testi sonuçlarına göre 1-3 arasında ve TDE öğrencileri için Anadolu lisesi mezunları lehine olduğu ve Post-hoc Scheffe testi sonuçlarına göre 1-2 arasında ve 2-3 arasında olduğu tespit edilmiştir. Mesleği sevme alt boyutunda sadece TDE öğrencileri adına anlamlı bir farklılık olduğu görülmektedir. Ortalamalara bakıldığında bu farkın Anadolu lisesi mezunları lehine olduğu ve Post-hoc Scheffe testi sonuçlarına göre 2-3 arasında olduğu tespit edilmiştir. Meslekle ilgili yeterlilik alt boyutunda yine sadece TDE öğrencileri lehine anlamlı bir farklılık tespit edilmiştir. Ortalamalara bakıldığında bu farkın yine Anadolu lisesi mezunları lehine olduğu ve Post-hoc Scheffe testi sonuçlarına göre 1-2 
arasında olduğu tespit edilmiştir. Bunlara ek olarak tutum ölçeğinin alt boyutu olan mesleğin gerekliliğine inanma ve yaşam boyu öğrenme eğilimleri adına herhangi anlamlı bir farklılığa rastlanmamıştır.

\section{SONUC VE TARTISSMA}

Çalışmada Türkçe öğretmeni adayları ve Türk Dili ve Edebiyatı öğretmeni adaylarının yaşam boyu öğrenme eğilimlerinin mesleğe yönelik tutumları ile ilişkisi incelenmiştir. $\mathrm{Bu}$ doğrultuda önce öğretmen adaylarının yaşam boyu öğrenme eğilimleri ve mesleğe yönelik tutumlarının ne düzeyde olduğunu tespit edebilmek amacıyla ortalama değerlere bakılmıştır. Elde edilen bulgulara göre her iki bölümde okuyan öğretmen adaylarının tutum ölçeğinin "mesleğe ilgi duyma" alt boyutunda iyi düzeyde olduğu az bir farkla TDE öğrencilerinin mesleğe karşı ilgi durumlarının daha iyi düzeyde olduğu tespit edilmiștir. Tutum ölçeğinin "mesleğe bağlılık" alt boyutunda her iki bölümde okuyan öğretmen adaylarının ortalamalarının iyi düzeyde olduğu yine az bir farkla TDE öğrencilerinin mesleğe bağlllık durumlarının daha iyi düzeyde olduğu söylenebilir. "Mesleği sevme" alt boyutunda ise her iki bölümde okuyan öğretmen adaylarının ortalamalarının orta düzeyde olduğu az bir farkla TDE öğrencilerinin mesleği daha çok sevdikleri söylenebilir. Ölçeğin "mesleğin gerekliliğine inanma" alt boyutunda her iki bölümde okuyan öğretmen adaylarının ortalamalarının iyi düzeyde olduğu yine az bir farkla TDE öğrencilerinin mesleğin gerekli olduğuna inanma durumlarının daha iyi düzeyde olduğu söylenebilir. "Meslekle ilgili yeterlilik düzeyleri" alt boyutunda her iki bölümde okuyan öğretmen adaylarının ortalamalarının orta düzeyde olduğu yine az bir farkla TDE öğrencilerinin meslekle ilgili yeterlilik düzeylerinin daha iyi durumda olduğu söylenebilir. "Yaşam Boyu Öğrenme Eğilimleri" her iki bölümde okuyan öğretmen adaylarının ortalamalarının orta düzeyde olduğu az bir farkla Türkçe öğrencilerinin yaşam boyu öğrenme eğilimlerinin daha iyi düzeyde olduğu söylenebilir. Bu sonuç TDE öğretmen adaylarının meslekle ilgili Türkçe öğretmen adaylarına oranla daha olumlu bir tutuma sahip oldukların göstermektedir. Bu durum TDE öğrencilerinin son sınıfta pedagojik formasyon almaları ve staj uygulamalarına daha yeni çıkıyor olmaları nedeniyle meslekle ilgili bir olumlu bakış açısı geliştirmiş olabilecekleri düşüncesiyle açıklanabilir. Bu durum ayrıca atanma durumlarının Türkçe öğretmen adaylarına nazaran daha zor olması ile de açıklanabilir. Türkçe öğretmen adaylarının yaşam boyu öğrenme eğilimlerinin daha iyi düzeyde olması ise Eğitim Fakülteleri'ndeki sürekli ve yenilenen uygulamalı ve yapılandırmacı eğitimle açıklanabilir. Bu durum Türkçe öğretmen adaylarının birinci sınıfa başladıkları andan itibaren öğretmen olacakların bildikleri ve bu doğrultuda kendilerini geliştirdikleri düşüncesi ile de açıklanabilir.

Araştırmadan elde edilen sonuçlara göre öğretmen adaylarının öğretmenlik mesleğine yönelik tutum düzeylerinin olumlu ve iyi düzeyde olduğu söylenebilir. Bu bulgumuzu destekleyen bazı çalışmalara rastlanmıştır (Çetinkaya, 2009; Terzi ve Tezci, 2007; Özder, Konedrali, ve Zeki, 2010; Can, 2013). Buna ek olarak yaşam boyu öğrenme eğilimlerinin ise orta düzeyde olduğu tespit edilmiştir. Ancak literatürde bunun aksi olarak yaşam boyu öğrenme eğilimleri ile ilgili sonuçları "yüksek düzeyde" (Ergün ve Cömert Özata, 2016; Yılmaz, 2016; Oral ve Yazar, 2015; Kılıç ve Tuncel, 2015; Erdamar, Demirkan, Saraçoğlu ve Alpan, 2017) ve "düşük düzeyde" (Diker Coşkun ve Demirel, 2012; Tunca, Şahin ve Aydın, 2015) olarak tespit edilmiş çalışmalara rastlanmıştır.

Elde edilen bir diğer sonuç ise tutum ölçeğinin alt boyutları (mid, mb, ms, mgi, miyd,) ve yaşam boyu öğrenme eğilimleri arasında bir ilişki olup olmadığıdır. Yapılan korelasyon analizi sonuçlarına göre tutum ölçeğinin alt boyutları arasında "mesleği sevme ile mesleğin gerekliliğine inanma" yüksek düzeyde pozitif bir ilişki tespit edilmiştir. Diğer yandan yine tutum ölçeğinin alt boyutları arasında "mesleğe ilgi duyma ile mesleğin gerekliliğine inanma", "mesleğe ilgi duyma ile mesleğe bağlılık", "mesleğe ilgi duyma ile mesleği sevme" arasında orta düzeyde pozitif yönde bir iliş̧ki olduğu tespit edilmiştir. Mesleğe yönelik duygu ve düşüncelerin birbirini olumlu anlamda desteklediği ve birinin artışından diğerinin de olumlu yönde arttığı söylenebilir. Yani meslekle ilgili olumlu tutum mesleğin her yönüyle sevilmesini ve olumlu bir bakış açısı geliştirmelerini sağlamıştır denebilir. Tutum ölçeğinin alt boyutu olan "mesleğe bağlllık" ile "yaşam boyu öğrenme eğilimleri" arasında negatif yönde en zayıf bir ilişki olduğu tespit edilmiştir. Buna göre öğretmen adaylarının yaşam boyu öğrenme eğilimleri azaldıkça mesleğe yönelik tutumları artmaktadır denebilir. Bunun dışında öğretmen adaylarının yaşam boyu öğrenme eğilimleri ile mesleğe yönelik tutumları arasında diğer alt boyutlarda herhangi anlamlı bir farklılık tespit edilmemiştir. Elde edilen bu bulgunun aksine Çam ve Üstün (2016) yaptıkları bir çalışmada öğretmenlerin mesleki tutumları ile yaşam boyu öğrenme eğilimleri arasında pozitif yönlü orta düzey bir ilişki olduğunu tespit etmişlerdir. Ayra ve Kösterelioğlu (2015) ise yaptıkları bir çalışmada Öğretmenlerin yaşam boyu öğrenme eğilimleri ve mesleki öz yeterlik algıları arasında pozitif yönlü düşük düzeyde anlamlı bir iliş̧i tespit etmişlerdir. Özgür (2016) yaptığı bir çalışmada öğretmen adaylarının yaşam boyu öğrenmede yeterlikleri ile bilgi okuryazarlığı öz-yeterliği arasında anlamlı, pozitif ve orta düzeyde bir ilişki olduğunu tespit etmiştir.

Çalışmadan elde edilen bir sonuç da Türkçe öğretmeni adayları ve Türk Dili ve Edebiyatı öğretmeni adaylarının yaşam boyu öğrenme eğilimlerinin ve mesleğe yönelik tutumlarının cinsiyet değişkenine göre faklılık gösterip göstermediğidir. Türkçe ve Türk Dili ve Edebiyatı öğretmeni adaylarının yaşam boyu öğrenme eğilimlerinin ve mesleğe yönelik tutumlarının cinsiyet değişkeni bakımından tutum ölçeğinin bazı alt boyutlarında anlamlı farklılık gösterdiği tespit edilmiştir. Mesleğe ilgi duyma alt boyutunda anlamlı farklılığın Türkçe öğretmeni adayları adına olduğu, ortalamalara bakıldığında ise bu farkın kız öğrencilerin lehine olduğu görülmektedir. Mesleğe bağlılık boyutunda ise her iki grupta yer alan öğretmen adayları lehine bir anlamlı farklılık 
olduğu görülmektedir. Ortalamalara bakıldığında TDE öğrencilerinin Türkçe öğrencilerine oranla daha iyi ortalamalara sahip olduğu dikkat çekmektedir. Buna ek olarak bu alt boyutta anlamlı farklılı̆ıı her iki grupta da kız öğrenciler lehine olduğu tespit edilmiştir. Mesleği sevme ve mesleğin gerekliliğine inanma alt boyutlarında da anlamlı bir farklılık olduğu ve bu farklılığın iki alt boyutta da Türkçe öğrencileri adına olduğu, ortalamalara bakıldığında ise bu farkın kız öğrencilerin lehine olduğu tespit edilmiştir. Bunlara ek olarak tutum ölçeğinin diğer alt boyutlarında ve yaşam boyu öğrenme eğilimleri ölçeğinin cinsiyet değişkeni bakımından herhangi anlamlı bir farklılığa da rastlanmamıştır. Yaşam boyu öğrenme eğilimleri ile ilgili yapılan çalışmalarda benzer (Çam ve Üstün, 2016; Oral ve Yazar, 2015; Yaman ve Yazar, 2015; Tunca, Şahin ve Aydın, 2015) ve farklı (Özçiftçi ve Çakır, 2015; Dikmen, Yuvacı ve Erol, 2017; Kılıç ve Tuncel, 2015; Erdamar, Demirkan, Saraçoğlu ve Alpan, 2017) sonuçlara rastlanmıştır. Mesleğe yönelik tutum açısından elde edilen bulguyu destekleyen sonuçlara rastlanmıştır (Çapa ve Çil, 2000; Pehlivan, 2008; Üstüner, Demirtaş ve Cömert, 2010; Erdem, 2012; Çetinkaya, 2009; Terzi ve Tezci, 2007; Aydın ve Sağlam, 2012; Polat, 2013).

Çalışmada Türkçe öğretmeni adayları ve Türk Dili ve Edebiyatı öğretmeni adaylarının yaşam boyu öğrenme eğilimlerinin ve mesleğe yönelik tutumlarının bölüm değişskenine göre faklılık gösterip göstermediği ile ilgili elde edilen bulgular ışığında; tutum ölçeğinin mesleğe ilgi duyma, mesleğe bağlllık ve meslekle ilgili yeterlilik alt boyutlarında anlamlı farklılık olduğu tespit edilmiş̧tir. Bu farklılı̆ı̆n TDE öğrencileri lehine olduğu görülmektedir. Literatür tarandığında benzer bir sonuca rastlanmıştır (Polat, 2013). Tutum ölçeğinin diğer alt boyutlarında ve yaşam boyu öğrenme eğilimleri ölçeği adına bölüm değişkeni bakımından herhangi anlamlı bir farklılığa rastlanmamıştır. Yaşam boyu öğrenme eğilimleri ile ilgili elde edilen sonucu destekleyen bazı çalışmalara rastlanmıştır (Oral ve Yazar, 2015; Kılıç, 2014).

Araştırmada Türkçe öğretmeni adayları ve Türk Dili ve Edebiyatı öğretmeni adaylarının yaşam boyu öğrenme eğilimlerinin ve mesleğe yönelik tutumlarının yaş değişkenine göre faklılık gösterip göstermediğini ile ilgili elde edilen bulgulara göre; tutum ölçeğinin mesleğe bağlll1k alt boyutunda ve yaşam boyu öğrenme eğilimleri ölçeğinde anlamlı farklılık olduğu tespit edilmiş̧tir. Mesleğe bağlılık alt boyutunda Türkçe öğrencileri, yaşam boyu öğrenme eğilimleri alt boyutunda ise TDE öğrencileri adına anlamlı farklılık olduğu ortalamalara her iki alanda da 4. $(27,28,29)$ grup lehine olduğu söylenebilir. Post-hoc Scheffe testi sonuçlarına göre farklılığın her iki alanda da 3-4 grupları arasında olduğu tespit edilmiştir. Bu sonuca göre yaş düzeyi arttıkça Türkçe öğretmen adayları için, mesleğe yönelik olumlu düşünceler ve TDE öğretmen adayları için öğrenme ile ilgili olumlu düşünceler artmaktadır denebilir. Benzer sonuçları olan bazı çalışmalar vardır (Erdem, 2012;Can, 2013; Kılıı̧, 2014; Ergün, ve Cömert Özata, 2016). Farklı sonucu olan bir çalışmaya da literatürde rastlanmıştır (Çam ve Üstün, 2016).

Çalışmada Türkçe öğretmeni adayları ve Türk Dili ve Edebiyatı öğretmeni adaylarının yaşam boyu öğrenme eğilimlerinin ve mesleğe yönelik tutumlarının mezun olunan lise türü değişkenine göre faklılık gösterip göstermediği ile ilgili elde edilen bulgulara göre; tutum ölçeğinin mesleğe ilgi duyma, mesleğe bağlllık, mesleği sevme ve meslekle ilgili yeterlilik alt boyutlarında anlamlı farklılık olduğu görülmektedir. Literatürde bu bulgunun aksine sonuçlara ulaşılmıştır (Çetinkaya, 2009; Terzi ve Tezci, 2007; Polat, 2013; Can, 2010). Bu farkın mesleğe ilgi duyma alt boyutunda Türkçe öğrencileri için düz lise mezunları lehine olduğu ve TDE öğrencileri için Anadolu lisesi mezunları lehine olduğu tespit edilmiştir. Mesleğe bağllık alt boyutunda ise yine Türkçe öğrencileri için düz lise mezunları lehine TDE öğrencileri için Anadolu lisesi mezunları lehine olduğu tespit edilmiştir. Mesleği sevme alt boyutunda sadece TDE öğrencileri adına anlamlı bir farklılık olduğu görülmektedir. Bu farkın Anadolu lisesi mezunları lehine olduğu tespit edilmiştir. Meslekle ilgili yeterlilik alt boyutunda yine sadece TDE öğrencileri lehine anlamlı bir farklılık tespit edilmiştir. Bu farkın yine Anadolu lisesi mezunları lehine olduğu tespit edilmiştir. Bunlara ek olarak tutum ölçeğinin alt boyutu olan mesleğin gerekliliğine inanma ve yaşam boyu öğrenme eğilimleri adına herhangi anlamlı bir farklılığa rastlanmamıştır. Literatürde yaşam boyu öğrenme eğilimleri ile ilgili sonucu destekleyen bazı çalışmalara rastlanmıştır (Yaman ve Yazar, 2015; Dikmen, Yuvacı ve Erol, 2017; Yilmaz, 2016).

\section{KAYNAKÇA}

Akkuş, N. (2008). Yaşam boyu öğrenme becerilerinin göstergesi olarak 2006 PISA sonuçlarının Türkiye açısından değerlendirilmesi. Yayımlanmamış Yüksek Lisans Tezi, Hacettepe Üniversitesi, Ankara.

Aydın, R., ve Sağlam, G. (2012). Öğretmen adaylarının öğretmenlik mesleğine yönelik tutumlarının belirlenmesi. Türk Eğitim Bilimleri Dergisi, 10(2). 257-94.

Ayra, M., ve Kösterelioğlu, İ. (2015). Öğretmenlerin yaşam boyu öğrenme eğilimlerinin mesleki öz yeterlik algiları ile ilişkisi. Education Sciences, 9(5), 17-28.

Ayra, M., Kösterioğlu, İ. ve Çelen, Ü. (2016). Öğretmenlerin yaşam boyu öğrenme eğilimlerinin çeşitli değişkenler açısından incelenmesi, Hitit Üniversitesi Sosyal Bilimler Enstitüsü Dergisi, Y11 9, Say1 1, 497-516.

Büyüköztürk, Ş. (2008). Bilimsel araştırma yöntemleri. Ankara: Pegem Akademi Yayınları.

Can, Ş. (2013). Tezsiz yüksek lisans öğrencilerinin öğretmenlik mesleğine yönelik tutumları. Sosyal ve Beşeri Bilimler Araştırmaları Dergisi, (24), 13-28. 
Coşkun Diker, Y. (2009) “Üniversite öğrencilerinin yaşamboyu öğrenme eğilimlerinin bazı değişkenler açısından incelenmesi.'”Hacettepe Üniversitesi, Sosyal Bilimler Enstitüsü, Eğitim Bilimleri Bölümü, Eğitim Programları ve Öğretim Anabilim dalı. Yayınlanmamış doktora tezi. Ankara.

Coşkun, Y.D. ve Demirel, M.(2012). Üniversite Öğrencilerinin Yaşam Boyu Öğrenme Eğilimleri. Hacettepe Üniversitesi Ĕ̈itim Fakültesi Dergisi. 42. 108-120.

Çam, E., ve Üstün, A. (2016). Öğretmenlerin mesleki tutumları ile yaşam boyu öğrenme eğilimleri arasındaki ilişki. Hitit Üniversitesi Sosyal Bilimler Enstitüsü Dergisi, 9(1).459-475.

Çapa, Y., ve Çil, N. (2000). Öğretmen adaylarının öğretmenlik mesleğine yönelik tutumlarının farklı değişkenler açısından incelenmesi. Hacettepe Üniversitesi Eğitim Fakültesi Dergisi, 18(18).69-73.

Çetinkaya, Z. (2009). Türkçe öğretmen adaylarının öğretmenlik mesleğine ilişkin tutumlarının belirlenmesi. İlkögretim Online, 8(2). 298-305.

Dikmen, Y., Yuvacı Uslu, H. ve Erol, F. (2017). Tıp fakültesi öğrencilerinin yaşam boyu öğrenme eğilimlerinin incelenmesi International Journal of Human Sciences ISSN:2458-9489. 14(3),2399-2408.

Duman, A. (2007). Yetişskinler eğitimi, Ankara: Ütopya Yayınevi.

Erdamar, G., Demirkan, Ö., Saraçoğlu, G., ve Alpan, G. (2017). Lise öğretmenlerinin yaşam boyu öğrenme eğilimleri ve eğitsel internet kullanma öz-yeterlik inançları. Abant İzzet Baysal Üniversitesi Ĕgitim Fakültesi Dergisi, 17(2), 636-657.

Erdem, C. (2012). Türk Dili ve Edebiyatı öğretmeni adaylarını öğretmenlik mesleğine yönelik yeterlilik algıları ve tutumları üzerine bir araştırma. Turkish Studies International Periodical for the Languages, Literature and History of Turkish or Turkic, 7(4), 1727-1747.

Ergün, S., ve Cömert Özata, S. (2016). Okul öncesi öğretmenliği bölümüne devam eden öğrencilerin yaşam boyu öğrenme eğilimleri. International Journal of Human Sciences, 13(1), 1851-1861. doi:10.14687/ijhs.v13i1.3568

Hoşgörür, V. (2016). Eğitim fakültesi öğretim elemanlarının yaşam boyu öğrenmeye ilişkin görüşleri. Education Sciences, 11(3), 114-125.

Karasar, N. (2010). Bilimsel araştırma yöntemleri. Ankara: Nobel Yayınları.

Kılıç, Ç. (2014). Öğretmen adaylarının yaşam boyu öğrenmeye yönelik algıları. Eğitim ve öğretim araştırmaları dergisi. 3(4). 2146-9199.

Kılıç, H., ve Tuncel, Z. A. (2015). İlköğretim branş öğretmenlerinin bireysel yenilikçilik düzeyleri ve yaşam boyu öğrenme eğilimleri. International Journal of Curriculum and Instructional Studies, 4(7). 25-37.

Knowles, M. (1996). Yetişkin öğrenenler, Göz ardı edilen bir kesim. Ankara Üniversitesi Basımevi, Ankara.

Miser, R. (2006). İnternet ne öğretir? Fevziye Sayılan ve Ahmet Yıldız (Haz.). Yaşam boyu öğrenme içinde. (ss.5861). Ankara: Pegem A Yayıncılık.

Oral, B. ve Yazar, T. (2015). Öğretmen adaylarının yaşam boyu öğrenmeye ilişkin algılarının çeşitli değişkenlere göre incelenmesi. Elektronik Sosyal Bilimler Dergisi, 14(52).01-11.

Özder, H., Konedralı, G., ve Zeki, C. P. (2010). Öğretmen adaylarının öğretmenlik mesleğine yönelik tutumlarının çeşitli değiş̧kenler açısından incelenmesi. Kuram ve Uygulamada Eğitim Yönetimi Dergisi, 16(2), 253275.

Özgür, H. (2016). Öğretmen adaylarının yaşam boyu öğrenme yeterlikleri ve bilgi okuryazarlığı öz-yeterlikleri üzerine bir çalışma. Mersin Üniversitesi Ĕgitim Fakültesi Dergisi, 12(1).22-38.

Pehlivan, K. B. (2008). Sınıf öğretmeni adaylarının sosyo-kültürel özellikleri ve öğretmenlik mesleğine yönelik tutumları üzerine bir çalışma. Mersin Üniversitesi Eğitim Fakültesi Dergisi, 4(2).

Polat, S. (2013). Pedagojik Formasyon Sertifika Programı ve Eğitim Fakültesi Öğrencilerinin Öğretmenlik Mesleğine Yönelik Tutumlarının İncelenmesi/Investigating the Attitudes of Students from Pedagogical Formation Certificate Programs and Faculties of Education on the Prof. e-International Journal of Educational Research, 4(2).

Terzi, A. R., ve Tezci, E. (2007). Necatibey Eğitim Fakültesi öğrencilerinin öğretmenlik mesleğine ilişkin tutumları. Kuram ve Uygulamada Ĕ̈itim Yönetimi, 52(52), 593-614.

Tunca, N., Şahin, S. A., ve Aydın, Ö. (2015). Öğretmen adaylarının yaşam boyu öğrenme eğilimleri. Mersin Üniversitesi Ĕgitim Fakültesi Dergisi, 11(2). 432-446.

Üstüner, M., Demirtaş, H., ve Cömert, M. (2010). Öğretmen adaylarının öğretmenlik mesleğine yönelik tutumları (İnönü Üniversitesi, Eğitim Fakültesi Örneği). Eğitim ve Bilim, 34(151).

Yaman, F., ve Yazar, T. (2015). Öğretmenlerin yaşam boyu öğrenme eğilimlerinin incelenmesi (Diyarbakır ili örneği). Kastamonu Ĕ̈itim Dergisi, 23(4).1553-1566.

Yavuz Konokman, G. ve Yanpar Yelken, T. (2014). Eğitim fakültesi öğretim elemanlarının yaşam boyu öğrenme yeterliklerine ilişkin algıları. Hacettepe Üniversitesi Eğitim Fakültesi Dergisi, 29, 267-281.

Yılmaz, M. (2016). Öğretmenlerin Yaşam Boyu Öğrenme Eğilimlerinin İncelenmesi/Examination of Teachers' Lifelong Learning Tendencies. Mustafa Kemal Üniversitesi Sosyal Bilimler Enstitüsü Dergisi, 13(35). 253-262. 


\section{EXTENDED SUMMARY}

Introduction: Life-long learning is actually resembles learning by doing-experiencing. This is because individual does not know where and how learning will take place. Learning occurs faster and permanently for individual who learns by doing-experiencing, and this means success. "The understating of Life-long learning signifies that learning is not classified by the time and space and it is possible to learn at every age and every place" (Y1lmaz, 2016:254).

The person who will teach this skill to individuals is teachers. Continuously changing and renewed programs, fast developing technology, and the power to access the information may lead to problems for individuals concerningacquiring or using skills. Therefore, emotions and thoughts of teachers regarding these skills are the issues needed to be studied. "It is crucial to ensure employment of teachers with qualification to properly accomplish the profession of teaching, which requires numerous duties and responsibilities, in the system of education" (Ayra and Kösterelioğlu, 2015:19).

It is required to put emphasis on teachers, who constitute the basis of the present study and raise people by making their presence felt in every field, and the profession of teaching more sensitively. Special skill areas and professional attitudes and perceptions of these individuals, who raise the future of a country and whose job is working on human, and their life-long learning tendencies which are considerably necessary in today's world should be investigated carefully. According to Başbay, Ünver and Bümen (2009), ones of the most important goals of teacher training programs is that teachers develop positive attitudes towards this profession. Because, as also stated by Gürbüz and Kışoğlu (2007), positive attitude developed towards the profession is an important indicator of the success in that field. For this purpose, life-long learning tendencies of teacher candidates and students of pedagogic formation group and their attitudestowards the profession, and whether or not these concepts differed depending on several variables were investigated in the present study.

Method:The present study was conducted in survey model to compare studying approaches of students from Turkish teaching department and students from Turkish Language and Literature department. "Survey models are research approaches aiming to describe a previously or currently existing situation in the way it exists" (Karasar, 2010:77). The sample of the study consisted of the fourth-year students studying at Kafkas University Faculty of Education Department of Social Sciences and Turkish Education and the fourth-year students studying at Faculty of Arts and Sciences Department of Turkish Language Literatureand receiving pedagogical formation in the academic year of 2016-2017.

Results: It is possible to say that while mean scores of teacher candidateswereat good level in "interest inprofession" subscale of the attitude scale, interest of TLL students on the profession was higher with a slight difference.Mean scores of teacher candidates studying at both departments were high for "commitment to the profession" subscale of the attitude scale but commitment to profession was asserted to behigher again in TLL students with a slight difference. Mean scores of teacher candidates studying at both departments were at moderate level in "liking the profession" subscale but TLL students were asserted to like their profession more with a slight difference. Mean scores of teacher candidates studying at both departments were at good levelin "believing in necessity of the profession" subscale of the scale, but it could be asserted that the status of TLL students to believe in necessity of the profession was higher with a slight difference. Mean scores of teacher candidates studying at both departments were at moderate levelin "professional competency level" subscale, but professional competency of TLL students was higher with a slight difference. It can be told that mean scores of Mean scores of teacher candidates studying at both departments were at moderate levelin "Scale of Life-longLearning Tendencies" butlife-longlearning tendencies of Turkish students were better with a slight difference.

When correlation coefficients were examined, the highest positive correlation was observed to be between liking the profession and believing in necessity of the profession $\left(\mathrm{r}=.711^{* *}\right)$ subscales of the attitude scale. On the other hand, there was also a moderate positive correlation between the subscales of the attitudes scale. It was remarkable that these were between interest in profession and believing in necessity of the profession $(r=.630 * *)$, between interest in profession and commitment to the profession $\left(\mathrm{r}=.586^{* *}\right)$, and between interest in profession and liking the profession $\left(\mathrm{r}=.547^{* *}\right)$. It can be asserted that feelings and thoughts about the profession positively supported each other and if one increased, the other one also increased positively. In addition, the weakest negative correlation was observed to be between the commitment to the profession subscale of the attitude scale and lifelong learning tendencies $(\mathrm{r}=-.048)$.

Life-longlearning tendencies and attitudes towards the professionof Turkish teacher candidates and Turkish Language and Literature teacher candidates were determined to differ significantly in some subscales of the attitudes scale in terms of the variable of gender. The significant difference in the subscaleof interest in profession was in favor of Turkish teacher candidates; and when mean scores were examined, this difference was in favor of female students. A significant difference was observed in favor of teacher candidates of both groups in the subscaleof commitment to the profession. As mean scores were examined, it was remarkable that TLL students had higher mean scores compared to Turkish students. Furthermore, the significant difference in this subscale was in favor of female students in both groups. It was established that there wasalso a significant difference in the subscales of liking the profession and believing in necessity of the profession and this difference was in favor of 
Turkish students in both subscales. When mean scores were examined, the difference was in favor of female students. In addition, any significant difference was not also found in terms of other subscales of the attitude scale and life-long learning tendencies scale.

A significant difference was determinedin favor ofthe variable of department in interest in profession, commitment to the profession, and professional competency subscales of the attitude scale. This difference was observed to be in favor of TLL students. There was no significant difference in terms of the variable of department in other subscales of the attitude scale and the scale of life-longlearning tendencies.

Significant difference was determined for the variable of age in commitment to the profession subscale of the attitude scale and scale of life-longlearning tendencies. It can be asserted that while there was a significant difference in favor of Turkish students in commitment to the profession subscale, there was a significant difference in favor of TLL students in scale of life-longlearning tendencies, and mean scores were in favor of $4^{\text {th }}(27,28,29)$ group in both fields.

A significant difference was observed in favor of the variable of type of high school graduated in interest in profession, commitment to the profession, liking the profession, and professional competency subscales of the attitude scale. When mean scores were examined, this difference was detected to be in favor of general high school graduates for Turkish students in the subscaleof interest in profession, again in favor of general high school graduates for Turkish students and Anatolian high school graduates for TLL students in the subscale of commitment to the profession. There was a significant difference only in favor of TLL students in the subscaleof liking the profession. As mean scores evaluated, this difference was found to be in favor of Anatolian high school graduates. In the subscaleof professional competency, a significant difference was also determined only in favor of TLL students. When mean scores were examined, this difference was again in favor of Anatolian high school graduates. In addition, there was no significant difference in favor ofbelieving in necessity of the profession subscale of the attitude scale and for life-longlearning tendencies.

Conclusion And Discussion: According to the results obtained from the present study, it is possible to assert that attitude levels of teacher candidates towards teaching profession are positive and well. Some studies supporting this result of the present study have been found (Çetinkaya, 2009; Terzi and Tezci, 2007; Özder, Konedrali, and Zeki, 2010; Can, 2013). Their life-longlearning tendencies were also determined to be at moderate level. However, contrary to this, literature involves studies indicating the results as "high level"(Ergün and Özata, 2016; Yılmaz, 2016; Oral and Yazar, 2015; Kılıç and Tuncel, 2015; Erdamar, Demirkan, Saraçoğlu and Alpan, 2017) and "low level" (Diker Coşkun and Demirel, 2012; Tunca, Şahin and Aydın, 2015) in terms of lifelonglearning tendencies. This result showed that TLL teacher candidates had a more positive attitude about the professioncompared to Turkishteacher candidates. This situation may be explained by the opinion that TLL students might have developed a more positive professional approach because they receive pedagogical formation in the fourth yearand just get engaged ininternship applications. It is also can be explained by the fact that they are hardly appointed compared to Turkish teacher candidates. The fact thatTurkish teacher candidates had better levels of life-longlearning tendencies can be explained by constant and renewed applied and constructivist education in Faculties of Education. This is also associated with the opinion that Turkish teacher candidatesknow they will be a teacher from the moment they start the first year and they develop themselves accordingly.

Another result obtained from the study waswhether or not there was a correlation between subscales (mid, $\mathrm{mb}, \mathrm{ms}, \mathrm{mgi}$, miyd) of the attitude scale and life-longlearning tendencies. According to results of the correlation analysis, there was a highly positive correlation between "liking the profession and believing in necessity of the profession" subscales of the attitude scale. On the other hand, a moderate positive correlation was also determined between "interest in profession andbelieving in necessity of the profession", between "interest in profession and commitment to the job", and between "interest in profession and liking the profession". It is possible to say that feelings and thoughts about the profession positively supported each other and if one increased, the other one also increased positively. In other words, positive attitude towards the profession might have provided the profession to be loved in all aspects and students to develop a positive perspective. The weakest negative correlation was found between "commitment to the job" subscale of the attitude scale and "life-longlearning tendencies". Accordingly, attitudes of teacher candidatestowards the profession might be asserted to increase as their lifelonglearning tendencies decreased. Besides, any significant difference was not determined between lifelonglearning tendencies and professional attitudes of teacher candidates in terms of other subscales. In contrast to the present finding, the study by Çam and Üstün (2016) revealed a moderately positive correlation between professional attitudes and life-longlearning tendencies of teachers. In their study, Ayra and Kösterelioğlu (2015) determined a low positive significant correlationbetween life-longlearning tendencies and professional competency perceptions of teachers. In the study by Özgür (2016) it was found that there was a significant, positive, and moderate correlationbetween competencies of teacher candidates in life-longlearning and selfefficacy of information literacy.

Another result of the study waswhether or notlife-longlearning tendencies and professional attitudes of Turkish teacher candidatesand Turkish Language and Literature teacher candidates differed by the variableof gender. Life-longlearning tendencies and professional attitudes of Turkish and Turkish Language and Literature 
teacher candidatesshoweda significant difference in somesubscales of the attitude scale in terms of the variableof gender. This difference might be asserted to be in favor of female students. In addition, there was no significant difference in the scaleof life-longlearning tendenciesin terms of the variable of gender.Similar (Çam and Üstün, 2016; Oral and Yazar, 2015; Yaman and Yazar, 2015; Tunca, Şahin and Aydın, 2015) and different (Özçiftçi and Çakır, 2015; Dikmen, Yuvacı and Erol, 2017; Kılıç and Tuncel, 2015; Erdamar, Demirkan, Saraçoğlu and Alpan, 2017)results were found in studies onlife-longlearning tendencies. The results (Çapa and Çil, 2000; Pehlivan, 2008; Üstüner, Demirtaş and Cömert, 2010; Erdem, 2012; Çetinkaya, 2009; Terzi and Tezci, 2007; Aydın and Sağlam, 2012; Polat, 2013) supporting the result obtained in terms of attitude towards the profession were found.

In the light of results obtained in the study regarding whether or notlife-long learning tendencies and professional attitudes of Turkish teacher candidatesand Turkish Language and Literature teacher candidates differed in terms of the variable of department; there was a significant difference in interest in profession, commitment to the profession, and professional competency subscales of the attitude scale. This difference was observed to be in favor of TLL students. Literature review indicated the similar results (Polat, 2013). Any significant difference was not found in other subscales of the attitude scale and in the variable of department on behalf ofscale of life-long learning tendencies. Some studies supporting the result obtained about life-long learning tendencies were encountered (Oral and Yazar, 2015; Kılıç, 2014).

According to the results obtained in the study concerningwhether or notlife-long learning tendencies and professional attitudes of Turkish teacher candidatesand Turkish Language and Literatureteacher candidates differed in terms of the variable of age, a significant difference was determined in commitment to the professionsubscale of the attitude scale and in scale of life-long learning tendencies. It can be asserted that there was a significant difference in the behalf of Turkish students in commitment to the professionsubscale and in the behalf of TLL studentsin life-long learning tendencies subscale and mean scores were in favor of $4^{\text {th }}(27,28,29)$ group in both fields. According to the result, it was asserted that positive thoughts towards the professionincreased for Turkish teacher candidatesand positive thoughts about learning increasedfor TLL teacher candidatesas their age increased. There are some studies with similar results (Erdem, 2012;Can, 2013; Kılıç, 2014; Ergün, and Cömert Özata, 2016). A study revealing a different result was found in the literature(Çam and Üstün, 2016).

According to the results obtained in the study about whether or notlife-long learning tendencies and professional attitudes of Turkish teacher candidatesand Turkish Language and Literature teacher candidates differed in terms of the variable of type of high school graduated; a significant difference was observed in interest in profession, commitment to the profession, liking the profession, and professional competency subscales of the attitude scale. Literature involves results on the contrary of this result(Çetinkaya, 2009; Terzi and Tezci, 2007; Polat, 2013; Can, 2010). This difference was determined to be in favor of general high school graduates for Turkish students and Anatolian high school graduates for TLL students in the subscaleof interest in profession. In the subscale commitment to the profession, it was also in favor of general high school graduates for Turkish students and in favor of Anatolian high school graduates for TLL students. A significant difference was observed only in favor of TLL students in the subscale ofliking the profession. This difference was determined to be also in favor of Anatolian high school graduates. In subscale professional competency, there was a significant difference only for TLL students. This difference was in favor of Anatolian high school graduates. Moreover, any significant difference was not found in favor ofbelieving in necessity of the profession subscale of the attitude scale and lifelonglearning tendencies. In the literature, some studies supporting the result about life-longlearning tendencies have been found(Yaman and Yazar, 2015; Dikmen, Yuvacı and Erol, 2017; Yılmaz, 2016). 